\title{
Effects of nitrogen fertilization during raising of cauliflower transplants in cellular trays on plant growth
}

\section{R. BOOIJ}

DLO-Centre for Agrobiological Research (CABO-DLO), P.O. Box 14, NL 6700 AA Wageningen, Netherlands

Received: 7 October 1991; accepted: 6 December 1991

\begin{abstract}
The effects of nitrogen fertilization, applied by overhead irrigation of cauliflower plants during raising in cellular trays, on plant growth were studied. Increasing nitrogen concentration $\left(0-1.55 \mathrm{~g} \mathrm{l}^{-1}\right)$, applied twice a week, significantly increased plant dry weight, plant length and leaf area, but dry matter percentage was significantly decreased. Maximum dry matter production was reached when $0.47 \mathrm{~g} \mathrm{l}^{-1} \mathrm{~N}$ was applied, but expansion of leaf area continued to increase also at higher amounts. A linear relationship between leaf area and plant length was observed, independent of nitrogen fertilization regime and duration of the raising period. The large differences in plant characteristics as observed at the end of the raising period had almost disappeared three weeks after transplanting in the field. At final harvest, no significant differences between the treatments in time of harvest, duration of the harvest period or yield could be detected.
\end{abstract}

Keywords : Brassica oleracea var, botrytis, cauliflower, fertilization, nitrogen, plant raising, propagation

\section{Introduction}

Until recently, cauliflower crops were mainly produced from bare-root transplants. New transplant-raising systems, which are based on the 'speedling system' concept (Todd, 1982), were introduced at the beginning of the eighties in Europa (Royle, 1980). Plants are raised in cellular trays made of rigid plastic or polystyrene filled with a rooting medium. In comparison with the traditional systems, advantages in crop production are obvious (Salter, 1982; Gray, 1987) and mechanization of transplant raising is made possible to a high extent (Gray, 1987).

Because of the small volume per cell, rooting of the plant will be restricted and the available amount of water and nutrients per plant is limited. This enables a control of plant growth by adjustment of fertilization (mainly nitrogen) during raising to obtain the required type of transplant and to influence timing of transplant production.

The aim of the present experiments was to study how the availability of nitrogen affected growth and development of plants grown with a restricted rooting volume 


\section{R. BOOIJ}

and at a high plant density. Performance of the transplants produced in this way was assessed after transplanting in the field.

\section{Materials and methods}

Two identical experiments were conducted in 1986 and 1987 with the cauliflower cultivar Andes (Royal Sluis). Plants were raised in an unheated greenhouse in a polyethylene 'Growtray 216' (Rolloos Sorensen BV) containing 938 cells $\mathrm{m}^{-2}$, with a cell content of $10 \mathrm{ml}$ and a cell diameter of $2.4 \mathrm{~cm}$.

Cells were filled with a mixture of peat, sphagnum and vermiculite (DEGA BV). The medium contained $107 \mathrm{mg} \mathrm{kg}^{-1} \mathrm{~N}$. Two seeds were sown per cell and after emergence thinned to one plant. Plants were irrigated overhead twice a week

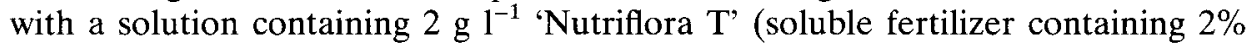
$\mathrm{N}, 4.8 \% \mathrm{P}$ and $33.2 \% \mathrm{~K}$ and trace elements) to which variable amounts of $\mathrm{Ca}\left(\mathrm{NO}_{3}\right)_{2}$ were added to obtain the required $\mathrm{N}$ concentrations $(0.12 ; 0.47 ; 0.90$; $\left.1.55 \mathrm{~g} \mathrm{l}^{-1}\right)$. EC values of the solutions were respectively $2.9,5.1,7.2,10.5, \mathrm{mS}$ $\mathrm{cm}^{-1}$ and $\mathrm{pH}$ values $6.2,6.1,6.0,5.9$. A plant received about $0.7 \mathrm{ml}$ of the nutrient solution each feeding time. In between feeds, tap-water was applied, and untreated plants received only tap-water.

Seeds were sown on two occasions, so that at the transplanting date, plants were 6 or 8 weeks old. A treatment was replicated three times and a replicate consisted of one tray (216 plants). Plant characteristics were determined just before transplanting. From 7 plants, taken randomly, the number of leaves (including scars) which had attained a length of at least $1 \mathrm{~cm}$ (further referred to as visible leaves), shoot fresh and dry weight, root dry weight, leaf area and leaf dry weight, stem length (between cotyledons and vegetation point) and total shoot length (between cotyledons and the longest leaf tip) were recorded. Dry weight was determined after $48 \mathrm{~h}$ drying at $75^{\circ} \mathrm{C}$.

Plants were transplanted, in 1986 on 7 July and in 1987 on 23 June, in 3 randomized blocks on a fertile marine clay soil at the Research Station for Arable Farming and Production of Field Vegetables (PAGV) in Lelystad (Netherlands). Plants were spaced at $60 \times 60 \mathrm{~cm}$ and each plot contained 56 plants for final harvest. Untreated plants were not transplanted. In between two rows, extra plants (8) were planted, which were harvested 3 weeks after transplanting, to get an impression about re-growth after transplanting. From these plants the number of visible and dead leaves (scars), leaf area, and shoot fresh and dry weight were determined.

Before transplanting, $250 \mathrm{~kg} \mathrm{ha}^{-1} \mathrm{~N}$ (ammonium nitrate limestone) was applied and immediately after transplanting, overhead irrigation $(15 \mathrm{~mm})$ was applied; further, husbandry, pest and disease control accorded to commercial practice. Curds were harvested just before these grew lose and from each curd, size grade (diameter classes: $17-20 \mathrm{~cm} ; 14-17 \mathrm{~cm} ; 11-14 \mathrm{~cm}$ ) and quality for fresh market were assessed.

Regression analysis and analysis of variance (ANOVA) was carried out with the statistical program package GENSTAT (Lane et al., 1987). 


\section{Results}

The overall mean of each variable differed for the two experiments, but the residual variation obtained from an ANOVA of the separate experiments appeared to be quite similar for the two experiments. The interaction between experimental year and the treatments could be neglected. Therefore the means of the two experiments are presented and the corresponding standard errors are based on all replicates $(2 \times 3)$.

\section{Transplants}

At the time of transplanting, plants differed in colour. Plants that had received no $\mathrm{N}$ or only $0.12 \mathrm{~g} \mathrm{l}^{-1}$ were almost purple, while plants which had received the highest dose were dark green.

Increasing the amount of $\mathrm{N}$ increased drastically total dry weight per plant at both plant ages until $0.47 \mathrm{~g} \mathrm{l}^{-1} \mathrm{~N}$ was applied; higher amounts hardly resulted in higher plant dry weights (Figure 1A), indicating that maximum dry matter production was reached at this amount of $\mathrm{N}$ applied. A strong increase in plant dry weight could be observed in the period between 6 and 8 weeks after sowing (Figure 1A). Although there were significant effects of $\mathrm{N}$ dose and plant age on the distribution of dry matter between shoot and root, the effects were small (Figure 1B). Dry matter percentage decreased from approximately $25 \%$ to $12 \%$ (Figure 1C) at increasing $\mathrm{N}$ dose, resulting in less hardened plants at higher $\mathrm{N}$ doses. Also the decrease in dry matter percentage levelled off at higher amounts of $\mathrm{N}$ applied (Figure 1C).

Leaf area per plant increased considerably at increasing amount of $\mathrm{N}$ over the whole range of $\mathrm{N}$ levels applied (Figure 1D). The values for leaf area per plant correspond with LAI (Leaf Area Index) values ranging from approximately 1 to 9. Increasing leaf area per plant is mainly due to a higher expansion rate of the leaves at increasing $\mathrm{N}$ dose and not to a higher number of leaves. Although the number of visible leaves is affected significantly by the $\mathrm{N}$ dose (Figure 1E), the area per leaf increased at increasing $\mathrm{N}$-dose in almost a similar way as total leaf area per plant (Figure $1 \mathrm{~F}$ ). Increase in area per leaf at increasing $\mathrm{N}$ dose resulted from the spread of dry matter over a larger area, because the dry weight per leaf was not influenced by the $\mathrm{N}$ dose (Figure $1 \mathrm{G})$, so that specific leaf weight $\left(\mathrm{g} \mathrm{cm}^{-2}\right)$ decreased at increasing $\mathrm{N}$ dose.

As the area per leaf was nearly the same for both plant ages (Figure 1F), the difference in leaf area per plant is mainly due to the difference in the number of visible leaves between the two plant ages. Weight per leaf increased considerably in the period between 6 and 8 weeks after sowing (Figure 1G) and while area per leaf did not increase (Figure 1F), dry matter is accumulated in the leaves during this period. Total dry matter production per plant per day was hardly affected by the $\mathrm{N}$ dose above $0.5 \mathrm{~g} \mathrm{l}^{-1}$ during the period between 6 and 8 weeks after sowing (Figure 1A), while leaf area per plant increased at increasing $\mathrm{N}$ dose (figure 1D). Combining these two facts, indicates a decreasing net assimilation rate at increasing $\mathrm{N}$ availability. 
R. BOOIJ

\section{Total dry weight}

(g)

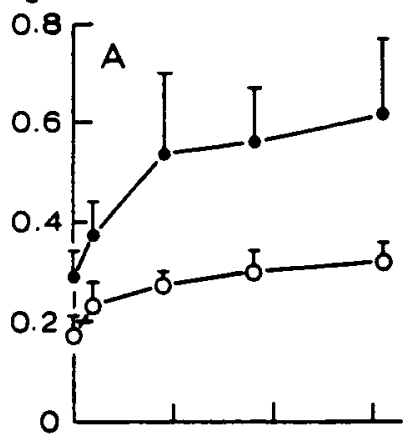

Shoot/Root

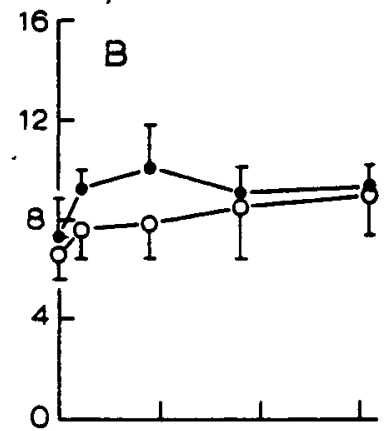

\section{Total leaf area}

$\left(\mathrm{cm}^{2}\right)$

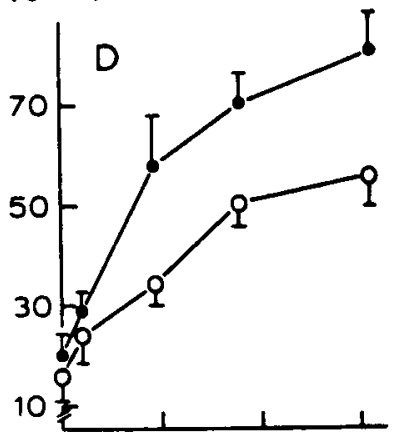

visible leaves

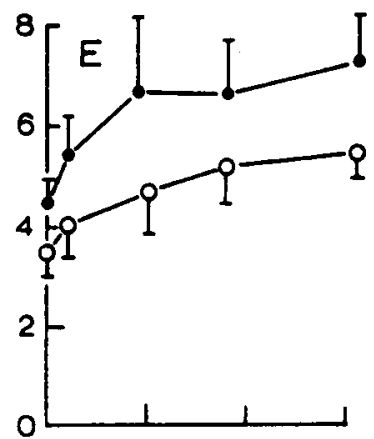

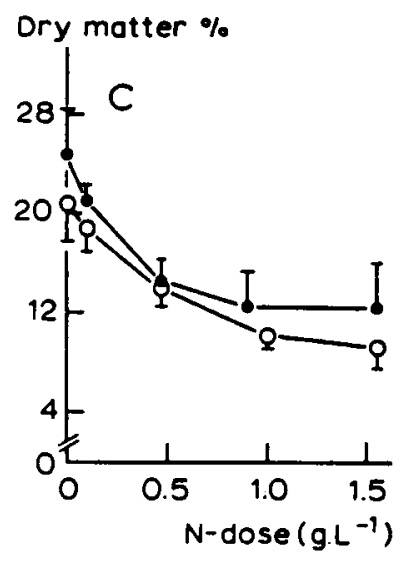

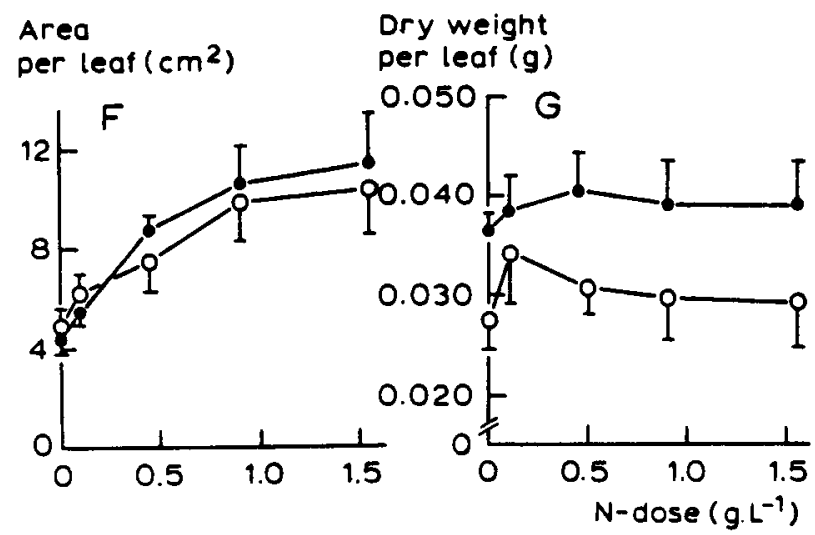

Fig. 1. Effect of nitrogen dose during raising on total plant dry weight $(\mathrm{g})$, shoot/root ratio, dry matter $\%$, total leaf area $\left(\mathrm{cm}^{2}\right)$ per plant, number of visible leaves, mean area per leaf $\left(\mathrm{cm}^{2}\right)$ and dry weight (g) per leaf at $6(0)$ or $8(0)$ weeks after sowing. Vertical bars indicate + or $-\mathrm{SE})$ 


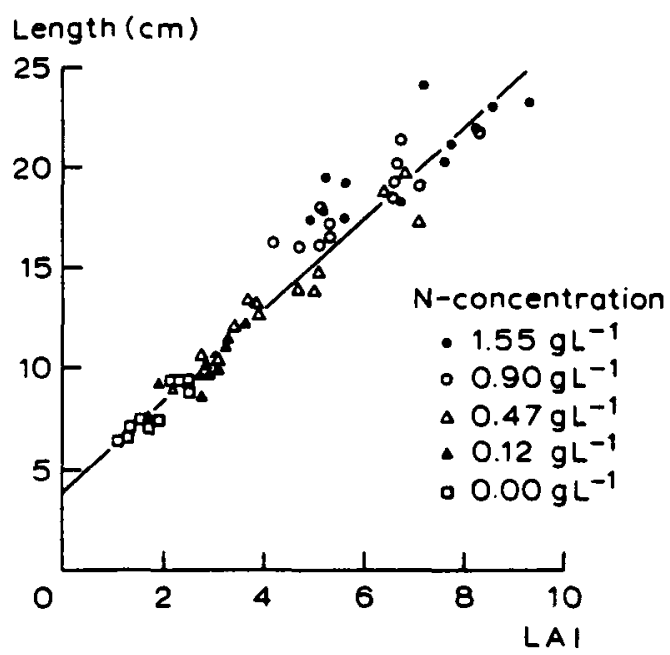

Fig. 2. Relationship between LAI and total length of cauliflower plants. For each fertilizer treatment data of separate experiments and plant ages are given. The equation of the linear regression line: $y$ $=2.3 x+3.9\left(\mathbf{R}^{2}=0.94\right)$

Leaf area per plant (expressed as LAI) was associated with length of the shoot, because a linear relation between LAI and total shoot length could be observed, independent of plant age, nitrogen dose and season (Figure 2). Stem length of the plants was highly correlated with total shoot length.

\section{Re-growth after transplanting}

Differences between treatments regarding the number of visible leaves, shoot dry weight and leaf area per plant were small three weeks after transplanting, although there was still a significant effect of $\mathrm{N}$ dose and plant age (Table 1). The number of dead leaves increased significantly at increasing $\mathrm{N}$ dose and was higher for the older transplants.

Dry matter percentage of the shoot was not affected by the treatment and for weight and area per leaf there was hardly a significant effect of $\mathrm{N}$ dose (Table 1).

\section{Harvest}

Time after transplanting on which $50 \%$ of the plants within a crop had reached maturity (75-78 days after transplanting) was not significantly affected by $\mathrm{N}$ dose or plant age, neither was length of the period during which plants within a crop matured (12-16 days). The proportion of plants that delivered a marketable curd $(91-98 \%)$ and size and quality of the harvested curds were not significantly influenced by the treatment which the plants had received during propagation. 


\section{R. BOOIJ}

Table 1. Effect of plant age at the time of transplanting and nitrogen dose during raising on the number of visible leaves, plant shoot dry weight $(\mathrm{g})$, plant leaf area $\left(\mathrm{cm}^{2}\right)$, dry matter percentage of the shoot and on area and dry weight per leaf; determined 3 weeks after transplanting in the field.

\begin{tabular}{|c|c|c|c|c|c|c|c|c|}
\hline \multirow[t]{2}{*}{$\begin{array}{l}\text { Age } \\
\text { (weeks) }\end{array}$} & \multirow[t]{2}{*}{$\begin{array}{l}\text { Dose } \\
\left(\mathrm{g} \mathrm{l}^{-1}\right)\end{array}$} & \multicolumn{2}{|c|}{$\begin{array}{l}\text { Number of } \\
\text { leaves }\end{array}$} & \multirow[t]{2}{*}{$\begin{array}{l}\text { Shoot dry } \\
\text { weight }(\mathrm{g})\end{array}$} & \multirow[t]{2}{*}{$\begin{array}{l}\text { Leaf area } \\
\left(\mathrm{cm}^{2}\right)\end{array}$} & \multirow[t]{2}{*}{$\begin{array}{l}\text { Shoot dry } \\
\text { matter \% }\end{array}$} & \multicolumn{2}{|l|}{ Leaf } \\
\hline & & visible & dead & & & & $\begin{array}{l}\text { area } \\
\left(\mathrm{cm}^{2}\right)\end{array}$ & $\begin{array}{l}\text { dry weight } \\
\text { (g) }\end{array}$ \\
\hline \multirow{4}{*}{. } & 0.12 & 11.8 & 0.3 & 2.85 & 335 & 12.2 & 29.3 & 0.20 \\
\hline & 0.47 & 12.3 & 0.7 & 3.37 & 376 & 12.4 & 32.2 & 0.23 \\
\hline & 0.90 & 13.1 & 1.4 & 2.70 & 281 & 12.2 & 23.8 & 0.17 \\
\hline & 1.55 & 13.6 & 1.6 & 3.45 & 355 & 11.9 & 29.3 & 0.21 \\
\hline \multirow{4}{*}{. } & 0.12 & 14.1 & 0.9 & 2.85 & 340 & 12.2 & 25.5 & 0.17 \\
\hline & 0.47 & 15.2 & 1.6 & 4.27 & 448 & 12.2 & 32.9 & 0.24 \\
\hline & 0.90 & 15.8 & 2.1 & 3.77 & 401 & 12.3 & 29.3 & 0.21 \\
\hline & 1.55 & 15.6 & 2.2 & 3.96 & 413 & 12.3 & 30.3 & 0.22 \\
\hline \multicolumn{2}{|c|}{ LSD 0.05} & 1.3 & 0.6 & 1.01 & 103 & ns & 6.4 & 0.05 \\
\hline
\end{tabular}

\section{Discussion}

Nitrogen fertilization largely affected plant growth, so that at the end of the raising period the size of the plant varied according to the level of nitrogen received, as was reported by several others authors (Will, 1985; Wurr et al., 1986; Tremblay \& Senécal, 1988; Hiron \& Paterson, 1990). Lower N supply restricted especially the expansion of leaf area (Figure 1D). Lower nitrogen availability will result in a decreased leaf nitrogen content (Robson \& Deacon, 1978) and a reduced leaf expansion rate (van Keulen et al., 1989). The increase of dry matter percentage and of weight per unit of leaf area at decreasing nitrogen availability might be due to accumulation of assimilates in leaves at increasing nitrogen deficiency (Robson \& Deacon, 1978). Due to the high plant density on the tray (about 400 times higher than of the crop in the field), leaf blades of plants grown at the higher $\mathrm{N}$ doses were forced to attain a more vertical position. This might have caused the relatively high LAI values (Figure 2) and the decreasing net assimilation rate at increasing $\mathrm{N}$ dose.

Length of the plants was controlled by the expansion of leaf area, as length increased at increasing leaf area, independent of plant age, nitrogen supply or the season (Figure 2). This can be the result of a decreasing red:far-red ratio below the canopy at increasing LAI, which stimulates stem elongation (Kasperbauer, 1971; Morgan \& Smith, 1981; Kasperbauer et al., 1984). The relation between leaf area and length of the plant indicates that it will be impossible to use nitrogen fertilization as an instrument to regulate length of the plant independently of leaf area at a set plant density. This hypothesis can be tested by comparing the effect of $\mathrm{N}$ supply at different plant densities. 
Three weeks after transplanting, differences between plants due to nitrogen supply and plant age had almost vanished, as was reported by Wurr et al. (1986). Re-growth of large plants after transplanting is perhaps reduced, because of a higher loss of older leaves (Table 1), while re-growth of nitrogen-deficient plants is probably relatively fast, due to the accumulation of non-structural carbohydrates in the leaves and stems during raising (Figure 1C,G; Robson \& Deacon, 1978), which can be mobilized and used for leaf expansion, when nitrogen is sufficiently available again after transplanting.

Time of maturity is mainly determined by the time of curd initiation (Booij, 1987) and the last is affected by the time at which juvenility ends and the temperature in the succeeding period (Booij, 1987, 1990a). The small differences in the number of visible leaves at three weeks after transplanting (Table 1) indicate that juvenility was terminated at the same time for all treatments, as the end of juvenility is characterized by the number of initiated leaves (Hand \& Atherton, 1987) and the total number of initiated leaves correlates with the number of visible leaves (Booij, 1990a). For the cultivar used, the juvenility is expected to end after 17-20 leaves have been initiated, which corresponds with 9-11 visible leaves. Therefore, all treatments will have received the same temperature during curd induction and time of curd initiation will have occurred at almost the same time for all treatments. If curd initiation should have occurred at the same time and no differences in plant weight three weeks after transplanting were obvious (Table 1), an effect of propagation treatment on curd weight is unlikely (Booij, 1990b).

An important practical implication of the present experiments is that nitrogen fertilization during raising of transplants in cellular trays can be aimed at requirements for hardening, length of the raising period, sturdiness, suitability for mechanical transplanting etc. One should realize, however, that the range of plant types was only tested under a limited range of environmental conditions, although Wurr et al. (1986) and Hiron \& Patterson (1990) found similar results.

\section{Acknowledgements}

Dr. A.P. Everaarts and Dr. S.C. van de Geijn are kindly acknowledged for their comments on the manuscript.

\section{References}

Booij, R., 1987. Environmental factors in curd intitation and curd growth of cauliflower in the field. Netherlands Journal of Agricultural Science 35: 435-445.

Booij, R., 1990a. Cauliflower curd initiation and maturity: variability within a crop. Journal of Horticultural Science 65: 167-175.

Booij, R., 1990b. Influence of transplant size and raising temperature on cauliflower curd weight. Gartenbauwissenschaft 55: 103-109.

Gray, D., 1987. Plant raising for modern transplanting systems. Acta Horticulturae 187: 17-23.

Hand, D.J. \& J.G. Atherton, 1987. Curd initiation in the cauliflower. I. Juvenility. Journal of Experimental Botany 38: 2050-2058. 


\section{R. BOOIJ}

Hiron, R.W.P. \& C.D. Paterson, 1990. The manipulation of plant development by control of nitrogen nutrition in cauliflowers raised in cellular trays, and effects on crop yield. Acta Horticulturae 267: 217-224.

Kasperbauer, M.J., 1971. Spectral distribution of light in a tobacco canopy and effects of end-of-day light quality on growth and development. Plant Physiology 47: 775-778.

Kasperbauer, M.J., P.G. Hunt \& R.E. Sojka, 1984. Photosynthate partitioning and nodule formation in soybean plant that received red or far-red light at the end of the photosynthetic period. Physiologia Plantarum 61: 549-554.

Lane, P., N. Galwey \& N. Lavey, 1987. Genstat 5. An introduction. Oxford University Press, Oxford, $163 \mathrm{pp}$

Morgan, D.C. \& H. Smith, 1981. Control of development in Chenopodium album L. by shadelight: the effect of light quantity (total fluence rate) and light quality (red:far-red ratio). New Phytologist 88: 239-248.

Robson, M.J. \& M.J. Deacon, 1978. Nitrogen deficiency in small closed communities of S24 rye-grass. II. Changes in the weight and chemical composition of single leaves during their growth and death. Annals of Botany 42: 1199-1213.

Royle, D., 1980. US wedge pushes blocks out. Grower 94(2): 15-18.

Salter, P.J., 1982. Advantages and disadvantages of 'module'-raised vegetable plants. Scientific Horticulture 33: 76-81.

Todd, G., 1982. The speedling system. Combined Proceedings of the International Plant Propagators Society 31: 612-616.

Tremblay, N. \& M. Senécal, 1988. Nitrogen and potassium in nutrient solution influence seedling growth of four vegetable species. Hort Science 28: 1018-1020.

Van Keulen, H., J. Goudriaan \& N.G. Seligman, 1989. Modelling the effects of nitrogen on canopy development and crop growth. In: G. Russell, B. Marshall \& P.G. Jarvis (Eds), Plant canopies: Their growth, form and function. SEB Seminar Series 31, Cambridge University Press, Cambridge, p. 83-104.

Will, H., 1985. Fertilization of vegetable transplants raised as Speedlings. Deutscher Gartenbau 39: $417-418$.

Wurr, D.C.E., E.F. Cox \& J.R. Fellows, 1986. The influence of transplant age and nutrient feeding regime on cauliflower growth and maturity. Journal of Horticultural Science 61: 503-508. 